\title{
Comparative Characterization of the Cellular Composition of the Black Scorpionfish (Scorpaena porcus L.) Hematopoietic Organs during the Spawning Season and the Period of Reproductive Inactivity
}

\author{
Aleksandra Y. Andreyeva*, Tatiana A. Kukhareva, \\ Ekaterina S. Kladchenko and Alexander A. Soldatov \\ Kovalevsky Institute of Biology of the Southern Seas of RAS \\ Sevastopol, Russian Federation
}

Received 13.03.2020, received in revised form 05.05.2020, accepted 10.01.2021

\begin{abstract}
Hematopoiesis in teleosts has a number of characteristics that are not fully understood. In the present work, the cellular composition of the hematopoietic organs (head kidney and spleen) of the black scorpionfish during the spawning season and the period of reproductive inactivity was studied using light microscopy. The morphology and the percentage of blood cells were described. The head kidney was shown to be the main hematopoietic organ of the black scorpionfish: immature blood cells of all hematopoietic lines at the different stages of differentiation were observed there. They were divided into 3 clusters depending on the average cell diameter. Lymphocytes, thrombocytes and colony-forming cells, the precursors for all types of blood cells, were observed within the cluster of small cells. The intermediate-size cluster comprised blast forms (erythroblasts and blasts of white blood cells). The large-size cluster consisted of maturing granulocytes, monocytes, macrophages, plasma cells, and mature erythrocytes. The spleen mainly contained mature erythrocytes, showing signs of senescence, and erythrocyte ghosts. Therefore, it was concluded that the spleen of the black scorpionfish performs the function of depositing and utilizing erythrocytes. The study also demonstrated the seasonal dynamics of hematopoiesis. The increase in the number of erythroblasts was recorded in the head kidney of spawning individuals. Erythroblasts were also found in the spleen, in spite of their total absence in the reproductively inactive fish. Consequently, the spleen of the black scorpionfish is an organ of secondary erythropoiesis, which functions when the hematopoietic capacity of the kidneys is insufficient.
\end{abstract}

(C) Siberian Federal University. All rights reserved

This work is licensed under a Creative Commons Attribution-NonCommercial 4.0 International License (CC BY-NC 4.0).

* Corresponding author E-mail address: andreevaal@gmail.com

ORCID: 0000-0001-7845-0165 (Andreyeva A.); 0000-0001-7151-4402 (Kukhareva T.); 0000-0001-9476-6573 (Kladchenko E.); 0000-0002-9862-123X (Soldatov A.) 
Keywords: hemopoiesis, hematopoietic organs, blood cells, spawning season, Scorpaena porcus L., light microscopy.

Acknowledgements. This work was performed to carry out the State Assignment (state registration number AAAA-A18-118021490093-4) and was supported by the Russian Foundation for Basic Research (Grant No. 20-44-920001)

Citation: Andreyeva A. Y., Kukhareva T. A., Kladchenko E. S., Soldatov A. A. Comparative characterization of the cellular composition of the black scorpionfish (Scorpaena porcus L.) hematopoietic organs during the spawning season and the period of reproductive inactivity. J. Sib. Fed. Univ. Biol., 2021, 14(2), 195-207. DOI: 10.17516/1997-1389-0347

\title{
Сравнительная характеристика клеточного состава
} кроветворных органов морского ерша (Scorpaena porcus L.) в период нереста и функционального покоя

\author{
А.Ю. Андреева, Т. А. Кухарева, \\ Е. С. Кладченко, А.А. Солдатов \\ Институт биологии южных морей \\ имени А. О. Ковалевского РАН \\ Российская Федерация, Севастополь
}

\begin{abstract}
Аннотация. Гемопоэз у костистых рыб обладает рядом особенностей, которые до конца не изучены. В настоящей работе методом световой микроскопии исследовали клеточный состав кроветворных органов (пронефроса и селезенки) у морского ерша (Scorpaena porcus Linnaeus, 1858) в период нереста и функционального покоя. Описаны морфологические характеристики и процентное содержание форменных элементов, встречаемых на мазках. Показано, что пронефрос является главным кроветворным органом у $S$. porcus, поскольку там найдены форменные элементы всех ростков гемопоэза, находящиеся на различных этапах дифференцировки. Для удобства они были поделены на три размерных кластера. Среди кластера мелких клеток, помимо лимфоцитов и тромбоцитов, были обнаружены колониеобразующие единицы - клетки-предшественники всех форменных элементов крови. Средний кластер был представлен бластными формами (эритробластами и бластами клеток белой крови). Крупный кластер составляли созревающие гранулоциты, моноциты, макрофаги, плазматические клетки и зрелые эритроциты. В селезенке находили преимущественно зрелые эритроциты, которые имели признаки старения, а также эритроцитарные тени, на основании чего сделан вывод, что селезенка у морского ерша выполняет функцию по депонированию и утилизации эритроцитов. Также в работе была показана сезонная динамика процессов гемопоэза, которая затрагивала, главным образом, эритропоэз. В пронефросе нерестящихся особей регистрировали увеличение числа эритробластов. В селезенке также обнаруживали эритробласты на фоне их полного отсутствия у рыб, находящихся в состоянии функционального покоя. Следовательно, селезенка у морского ерша является органом вторичного


эритропоэза, который функционирует тогда, когда кроветворные способности почек оказываются недостаточными.

Ключевые слова: гемопоэз, кроветворные органы, клетки крови, нерест, Scorpaena porcus L., световая микроскопия.

Благодарности. Работа выполнена в рамках госзадания (№ гос. регистрации АAАA-А18118021490093-4) и при частичной поддержке проекта РФФИ (№ 20-44-920001).

Цитирование: Андреева, А.Ю. Сравнительная характеристика клеточного состава кроветворных органов морского ерша (Scorpaena porcus L.) в период нереста и функционального покоя / А.Ю. Андреева, Т.А. Кухарева, Е.С. Кладченко, А.А. Солдатов // Журн. Сиб. федер. ун-та. Биология, 2021. 14(2). С. 195-207. DOI: 10.17516/1997-1389-0347

\section{Введение}

Организация процесса гемопоэза у костистых рыб и высших позвоночных характеризуется значительным сходством (Fijan, 2002 a, b). Известно, однако, что у рыб отсутствует красный костный мозг, функции которого выполняет пронефрос (головная почка) и селезенка (Catton, 1951; Zuasti, Ferrer, 1989; Rodriguez, 1995; Abdel-Aziz et al., 2010). При этом в специализации этих органов обнаруживается видовая специфичность. У большинства видов костистых рыб селезенка осуществляет функцию депонирования и утилизации старых эритроцитов (Abdel-Aziz et al., 2010; Witeska, 2013), а основную гемопоэтическую функцию берет на себя пронефрос (Kondera, 2011; Kondera, 2014). Вместе с тем, известны виды, у которых в селезенке происходит образование эритроцитов и лимфоцитов, а пронефрос специализируется только на формировании клеток белой крови, не осуществляя эритропоэз (Fänge, Nilsson, 1985).

Гематологические показатели и клеточный состав крови костистых рыб могут зависеть от времени года и связанных с этим факторов: температуры воды, концентрации растворенного кислорода, длины светового дня (Kohanestani et al., 2013). Отмечено, что летнее повышение температуры воды стиму- лирует увеличение концентрации гемоглобина, гематокрита и числа эритроцитов в крови рыб (Kavadias et al., 2004), а похолодание приводит к обратным изменениям: значение этих показателей и число лейкоцитов крови снижается (Collazos et al., 1998; Sala-Rabanal et al., 2003). Следует учитывать также, что интенсивность пролиферации клеток кроветворной ткани рыб зависит и от нерестового периода (Маслова, Тавровская, 1991; Soldatov, 2005a). Так, число незрелых эритроидных форм в циркулирующей крови бычка-кругляка повышалось в ходе нереста (Soldatov et al., 2012). У других видов рыб период нереста сопровождался снижением числа эритроцитов, гемоглобина и гематокрита и ростом числа лейкоцитов крови (Bridges et al., 1976; De Pedro et al., 2005).

Межвидовые различия обнаруживаются и в морфологических характеристиках эритроцитов рыб (Witeska, 2013). Особую сложность представляет дифференциация форменных элементов по стадиям зрелости, а также идентификация бластных форм в кроветворной ткани. Это отчасти объясняется тем, что традиционные методы изучения клеточного состава крови, применяемые на млекопитающих, не дают адекватных результатов при использовании на рыбах. Все эти факторы 
существенно усложняют изучение процесса гемопоэза у рыб.

Таким образом, цель настоящей работы - исследовать клеточный состав пронефроса и селезенки морского ерша (Scorpaena porcus Linnaeus, 1858) в период нереста, а также в стадии функционального покоя.

\section{Материалы и методы}

Работа выполнена на взрослых особях морского ерша (Scorpaena porcus L.): вес 84-134 г, длина 11-17 см. Рыбу отлавливали в Севастопольской бухте (Крым) при помощи ставного невода и доставляли в лабораторию в пластиковых баках объемом 50 л с принудительной аэрацией. Транспортировка длилась 30-40 мин.

После отлова особей рассаживали в аквариумы объемом 50 л. Плотность посадки составляла 50-70 л на одну особь. В аквариумах поддерживался естественный проток. Температура воды соответствовала температуре воды в море: в зимний период $12-14{ }^{\circ} \mathrm{C}$, в летний $-18-20{ }^{\circ} \mathrm{C}$. Фотопериод: 12 ч день 12 ч ночь. Особей кормили фаршем из малоценных видов рыб. Суточный пищевой рацион составлял 6-7 \% от массы тела. В данных условиях рыбу выдерживали в течение одной недели с целью снятия стресса, вызванного отловом и транспортировкой. В момент изъятия особей из аквариума применяли уретановый наркоз (Soldatov, 2005b).

В работе использовали подвижные активно питающиеся экземпляры (10 особей на группу). Особи, отловленные в зимний период, находились в состоянии относительного функционального покоя (стадия зрелости гонад - II-III); особи, отловленные в летний период, находились в стадии активного нереста (стадия зрелости гонад - IV-V). Определение стадии зрелости гонад проводилось по стандартному методу (Сакун, Буцкая, 1963).
Образцы селезенки и пронефроса механически измельчали в среде следующего состава: 128 мM NaCl, 3 мM KC1, 1,5 мМ $\mathrm{CaCl}_{2}, 1,5 \mathrm{MM} \mathrm{MgCl}_{2}, 15 \mathrm{mM}$ Hepes, 2,2 мM D-глюкозы (pH 7,8) (Tiihonen, Nikinmaa, 1991). Для удаления фрагментов тканей клеточную массу трижды отмывали в 1,5 мл среды при скорости 1500 об'мин ${ }^{-1}$ в течение 5 мин (центрифуга - Elmi CM-50). Осадок клеток использовали для изготовления мазков.

Мазки окрашивали по комбинированному методу Паппенгейма (Май-Грюнвальд + Романовского-Гимза). Просмотр препаратов и микрофотосъемку проводили на микроскопе БИОМЕД ПР-2 ЛЮМ, оборудованном камерой Levenhuk C NG Series. Просматривали 2000 клеток на препарат. Анализ микрофотографий и определение линейных характеристик клеток проводили в программе ImageJ 1.44 p. (Abràmoff et al., 2004; Schneider et al., 2012).

Статистическая обработка и графическое оформление полученных результатов осуществлялись с применением стандартного пакета Grapher (версия 7). Результаты представлены в виде $\bar{x} \pm \mathrm{SE}$. Достоверность различий оценивали при помощи t-критерия Стьюдента. О нормальности распределения судили по критерию Пирсона.

\section{Результаты}

Клеточный состав пронефроса

Среди клеток пронефроса скорпены были обнаружены форменные элементы всех ростков гемопоэза, находящиеся на различных этапах дифференцировки. Для удобства эти элементы были поделены на три кластера исходя из размерных характеристик: кластер мелких клеток, кластер средних клеток и кластер крупных клеток.

Кластер мелких клеток - диаметр 4-7 мкм. Данная размерная группа была 
образована клетками преимущественно округлой формы, диаметр которых составлял 4-7 мкм (рис. 1). Внутри группы клетки подразделялись на две размерные подгруппы. Самые мелкие клетки диаметром $4,5 \pm 0,2$ мкм обладали темно-фиолетовым ядром с плотной структурой и значительной долей гетерохроматина, а также узким ободком цитоплазмы светло-базофильных оттенков (рис. 1.1). Подобные морфологические признаки характерны для ряда форменных элементов, различить которые методом световой микроскопии не представляется возможным. В сосудах периферического русла описанные структуры идентифицируются как тромбоциты и малые лимфоциты. Однако, имея дело с кроветворными органами, необходимо учитывать, что схожие морфологические характеристики имеют и колониеобразующие единицы (KOE) - родоначальные клетки всех ростков гемопоэза. Поскольку в настоящей работе исследовали именно гомогенаты кроветворных органов, а не их отпечатки, это позволило учесть клетки, которые аттрактированы непосредственно в строме пронефроса. Следовательно, в данном случае часть подобных фор- менных элементов принадлежала именно к классу КОЕ. Лимфоциты и тромбоциты, в свою очередь, могли попасть в суспензию клеток непосредственно из сосудов периферического русла.

Среди подгруппы мелких клеток, по всей видимости, также присутствовали предшественники лимфоцитов и тромбоцитов: пролимфоциты и протромбоциты. Однако идентифицировать данные клеточные структуры методом световой микроскопии также затруднительно.

Более крупные клетки из данной размерной группы имели средний диаметр 6,5土0,1 мкм и представляли собой большие лимфоциты (рис. 1.2).

\section{Кластер средних клеток - диаметр} 8-9 мкм. Данная группа была образована бластными клетками крови всех ростков гемопоэза. Клетки имели диаметр 8,4 40,2 мкм, характеризовались крупным ядром, занимающим почти весь объем клетки, цвет которого варьировал от ярко-красного до темно-фиолетового (рис. 2). В цитоплазме, расположенной узким ободком вокруг ядра, часто наблюдалась выраженная перинуклеарная зона. Повышенное содержание эухрома-

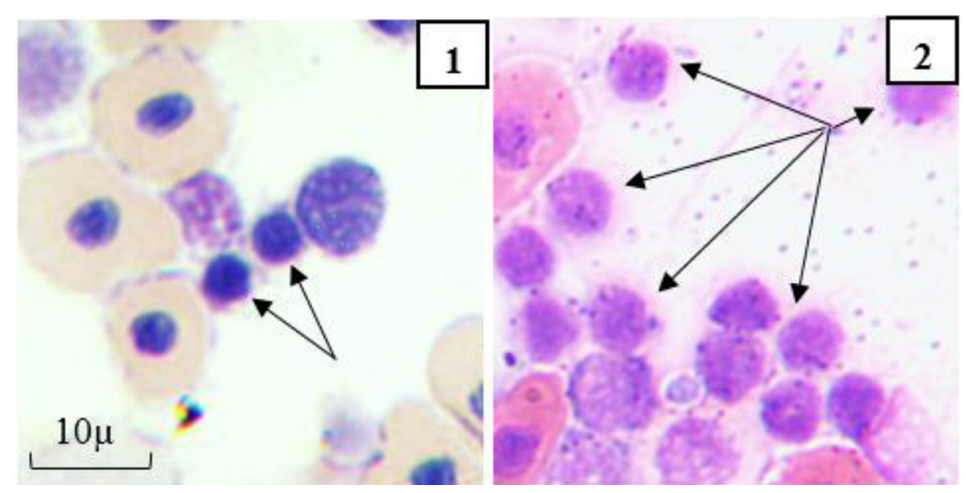

Рис. 1. Кластер клеток мелкого размера в пронефросе и селезенке Scorpaena porcus: 1 - колониеобразующие единицы, малые лимфоциты и тромбоциты; 2 - большие лимфоциты

Fig. 1. The cluster of small-size cells of head kidney and spleen of Scorpaena porcus: 1 - colony forming cells, small lymphocytes and thrombocytes; 2 - large lymphocytes 


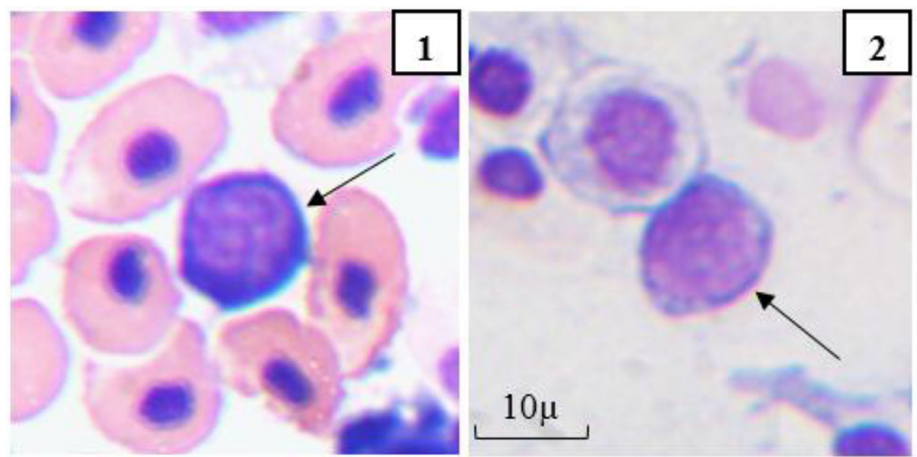

Рис. 2. Кластер клеток среднего размера в пронефросе и селезенке Scorpaena porcus: 1 - эритробласт; 2 - бласты клеток белой крови

Fig. 2. The cluster of intermediate-size cells of head kidney and spleen of Scorpaena porcus: 1 - erythroblast; 2 - blasts of white blood cells

тина свидетельствовало о высокой функциональной активности ядерных структур.

Ввиду схожести морфологических признаков у всех бластных форм при использовании методов световой микроскопии нами было выделено два типа данных клеток:

- Эритробласты, цитоплазма которых имела выраженную базофильную окраску (рис. 2.1).

- Бластные формы клеток белой крови, отличающиеся цитоплазмой светлых оттенков (рис. 2.2). Они включали в себя миелобласты, монобласты, лимфобласты и мегакариобласты.

Кластер крупных клеток - диаметр более 10 мкм. В кластер наиболее крупных клеток входили элементы диаметром более 10 мкм. Среди них были выделены все типы гранулоцитов, зрелые эритроциты, моноциты, макрофаги и плазматические клетки, находящиеся на различных этапах дифференцировки (рис. 3).

Макрофаги составляли группу наиболее крупных элементов среди всей рассмотренной клеточной популяции. Они имели непостоянную форму с разнообразными очертаниями (рис. 3.1). Средний диаметр большой оси

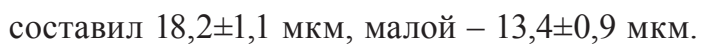

Ядро округлое или эллипсоидное, небольших размеров. Светло-базофильная цитоплазма содержала несколько крупных и множество мелких включений - фагосом.

Плазматические клетки имели округлую форму со средним диаметром 14,2 $\pm 0,5$ мкм. Бобовидное ядро содержало глыбки гетерохроматина и располагалось ацентрично в светло-базофильной цитоплазме (рис. 3.2).

На гистологических препаратах пронефроса были идентифицированы предшественники моноцитов, находящиеся на различных этапах дифференцировки. Это клетки округлой формы, со средним диаметром 11,4 \pm 0,3 мкм. Цитоплазма светлая, слегка базофильная (рис. 3.3). Бобовидное или округлое ядро красно-фиолетовой окраски располагалось ацентрично и занимало большую часть клетки.

Нейтрофилы, базофилы и эозинофилы представляли собой клетки округлой формы диаметром 10,4士0,1 мкм с достаточно крупными, ацентрично расположенными овальными ядрами, размер которых уменьшался по мере созревания (рис. 3.4-3.6). Хроматин в ядрах был деконденсирован. В цитоплазме обнаруживались мелкие гранулы различной окраски, соответствующей типу клетки. 


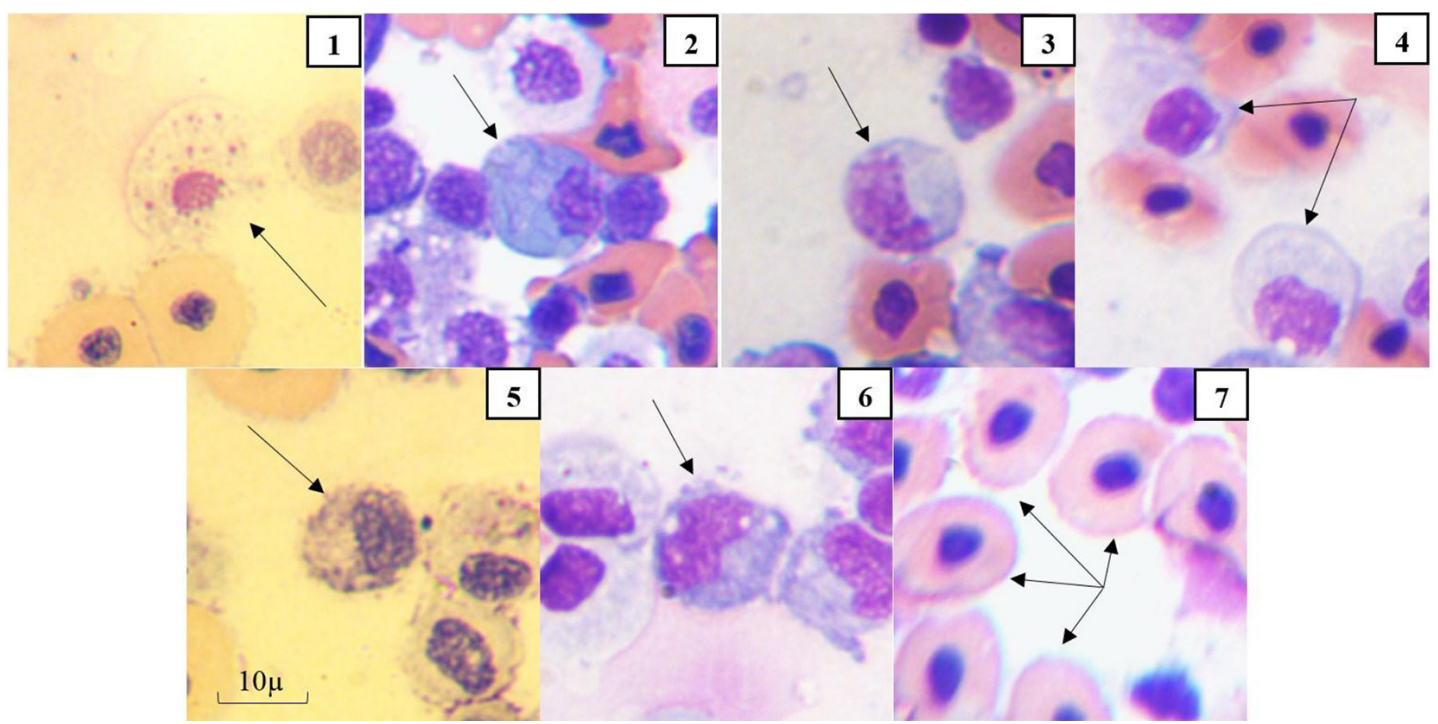

Рис. 3. Кластер клеток крупного размера в пронефросе и селезенке Scorpaena porcus: 1 - макрофаг; 2 плазматическая клетка; 3 - незрелый моноцит; 4 - незрелые нейтрофилы; 5 - незрелый эозинофил; 6 незрелый базофил; 7 - зрелые эритроциты

Fig. 3. The cluster of large-size cells of head kidney and spleen of Scorpaena porcus: 1 - macrophage; 2 - plasma cell; 3 -immature monocyte; 4 -immature neutrophils; 5 -immature eosinophil; 6 - immature basophil; 7 mature erythrocytes

Зрелые эритроциты скорпены, обнаруженные в пронефросе, имели эллипсоидную форму со средними размерами большой и малой оси $12,7 \pm 0,2$ и $9,7 \pm 0,2$ мкм соответственно. Небольшое ядро было плотной структуры с преобладанием гетерохроматина (рис. 3.7). Ацидофильная окраска цитоплазмы свидетельствовала о присутствии в ней молекул гемоглобина.

Помимо форменных элементов, на мазках выделялись эритроцитарные тени. Они представляли собой розоватые пятна, появляющиеся в результате разрушения эритроцитов. Однако ввиду отсутствия мембран у этих образований определить их размер не представлялось возможным.

\section{Клеточный состав селезенки}

В селезенке морского ерша были выделены две размерные группы клеток, соответствующие мелкому и крупному кластеру в суспензии пронефроса. Аналогично пронефросу, группа мелких клеток селезенки состояла из лимфоцитов, тромбоцитов и колониеобразующих единиц.

Крупный кластер клеток селезенки был образован преимущественно зрелыми эритроцитами. Эритроциты, найденные в селезенке, обладали более выраженной эллипсоидностью (большая ось - 12,2 $\pm 0,2$ мкм, малая $-7,9 \pm 0,2$ мкм) и часто имели некоторые нарушения формы (пойкилоцитоз), что характерно для стареющих эритроидных элементов. Отмечали также эритроциты с увеличенным объемом (макроциты), диаметр которых составил $18,2 \pm 0,6$ и $15,0 \pm 0,3$ мкм для большой и малой оси соответственно.

На мазках также присутствовали эритроцитарные тени. Другие форменные элементы в селезенке были малочисленны (менее 2 \%) и представляли собой эритробласты и клетки белой крови. 
Клеточный состав кроветворных органов в периоды покоя и нереста

У всех особей, находившихся в нерестовом состоянии, был отмечен рост числа бластных форм в пронефросе (рис. 4). В сравнении со стадией функционального покоя количество бластов белых клеток крови увеличилось в полтора раза и составило 9,3 $\pm 2,1 \%$, однако изменения не были достоверными. Содержание эритробластов увеличилось еще более - в 2,5 раза - и достигло значений $11,5 \pm 2,3 \%$ ( $>0,95)$. Одновременно регистрировалось некоторое снижение числа клеток наименьшей размерной группы (лимфоцитов, тромбоцитов и колониеобразующих единиц) у нерестящихся особей. Их доля среди клеток пронефроса составляла $23,3 \pm 7,5 \%$, что на $30 \%$ меньше, чем у особей в состоянии функционального покоя. Количество больших лимфоцитов снизилось на треть и составило $14,2 \pm 3,3 \%$.

Основную часть форменных элементов крупного кластера у всех исследуемых особей составили гранулоциты, находящиеся на различных этапах дифференцировки. Наиболее массовыми представителями этой группы были незрелые нейтрофилы. У особей, находящихся в состоянии функционального покоя, на их долю приходилось более 24 \% всей клеточной популяции пронефроса, у нерестящихся - более 37 \%. Число эозинофилов существенно не изменялось и находилось на уровне 2-3\%. Базофилы у рыб встречаются крайне редко (Иванова,

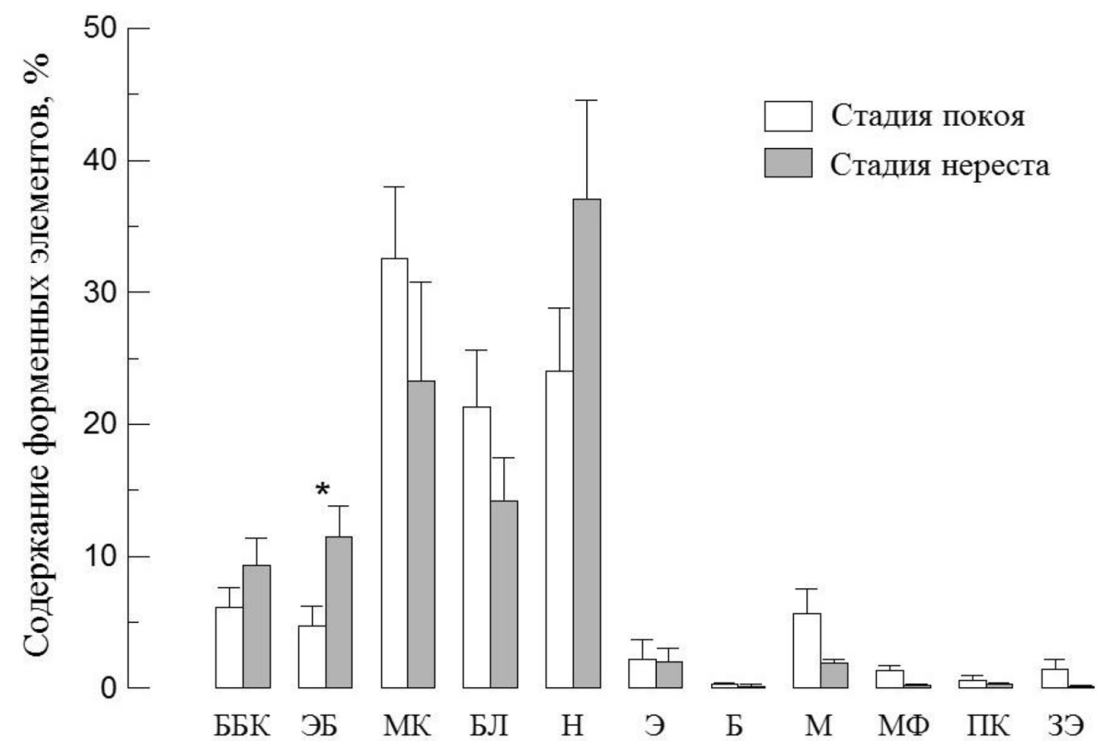

Рис. 4. Процентное содержание форменных элементов в пронефросе скорпены в зависимости от стадии нерестового периода: ББК - бласты клеток белой крови, ЭБ - эритробласты, МК - мелкие клетки (колониеобразующие единицы, лимфоциты и тромбоциты), БЛ - большие лимфоциты, Н - незрелые нейтрофилы, Э - незрелые эозинофилы, Б - незрелые базофилы, М - незрелые моноциты, МФ макрофаги, ПК - плазматические клетки, $3 Э$ - зрелые эритроциты. * - различия достоверны по tкритерию Стьюдента, $\mathrm{p}>0,95$

Fig. 4. The percentage of blood cells in head kidney during the different stages of the spawning season: ББК white blast cells, ЭБ - erythroblasts, МК - small cells (colony forming cells, lymphocytes, and thrombocytes), БЛ - large lymphocytes, $\mathrm{H}$ - immature neutrophils, Э - immature eosinophils, Б - immature basophils, $\mathrm{M}$ immature monocytes, МФ - macrophages, ПК - plasma cells, $3 \ni$ - mature erythrocytes. * - the means are significantly different (Student's t-test, $\mathrm{p}>0.95$ ) 


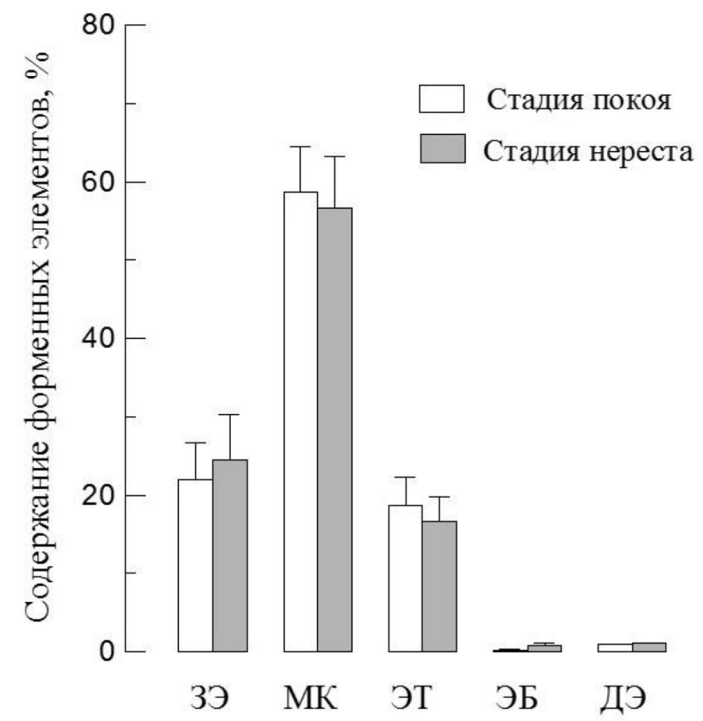

Рис. 5. Процентное содержание форменных элементов в селезенке скорпены в зависимости от стадии нерестового периода: $3 Э$ - зрелые эритроциты, МК - мелкие клетки (колониеобразующие единицы, лимфоциты, тромбоциты), ЭТ - эритроцитарные тени, ЭБ - эритробласты, ДЭ - другие форменные элементы

Fig. 5. The percentage of blood cells in spleen during the different stages of the spawning season: $3 \ni$ - mature erythrocytes, MK - small cells (colony forming cells, lymphocytes, thrombocytes), ЭT - erythrocyte ghosts, ЭБ - erythroblasts, ДЭ - other blood cells

1983), в нашем случае их было обнаружено менее $0,3 \%$.

Обратные изменения касались созревающих моноцитов. У нерестящихся особей их содержание регистрировалось на уровне $1,9 \pm 0,3 \%$, тогда как в состоянии функционального покоя их было в 3 раза больше.

Относительно содержания макрофагов, плазматических клеток и зрелых эритроцитов достоверных различий обнаружено не было, их количество не превышало $3 \%$ от всех форменных элементов пронефроса. Также встречались единичные случаи лизиса эритроцитов (эритроцитарные тени).

Клеточные популяции селезенки были представлены зрелыми эритроцитами, а также клетками мелкого кластера (тромбоцитами, колониеобразующими единицами и лимфоцитами). Их количество достоверно не изменялось в зависимости от нерестового периода (рис. 5). Кроме того, на мазках были отмечены эритроцитарные тени. Количество других форменных элементов не превышало $2 \%$, среди них наиболее массовыми представителями в нерестовый период были эритробласты $(0,86 \%)$.

\section{Обсуждение}

На мазках пронефроса морского ерша были идентифицированы клетки всех ростков линий кроветворения рыб: эритроидного, миелоидного и лимфоидного. Это позволяет заключить, что пронефрос является основным органом гемопоэза у морского ерша. Основную массу клеток пронефроса составляли незрелые элементы, находящиеся на разной стадии дифференцировки. Зрелые форменные элементы были относительно немногочисленны. По-видимому, они попали в суспензию из сосудов периферического русла 
в момент отбора образцов ткани. Очевидно, что при таком соотношении зрелых/незрелых клеток пронефрос является местом образования клеток крови, а не их резервирования. Подобные особенности были отмечены у различных видов рыб (Catton, 1951; Claver, Quaglia, 2009; Kondera, 2011; Kondera, 2014; Gordeev et al., 2019).

Отдельного внимания заслуживают макрофаги, плазматические клетки, а также моноциты, находящиеся на различных стадиях дифференцировки, обнаруживаемые нами на мазках пронефроса. Они свидетельствуют о том, что пронефрос морского ерша, помимо кроветворной функции, также играет роль иммунокомпетентного органа. Подобная специализация пронефроса характерна для костистых рыб (Tort et al., 2003). Макрофаги, плазматические клетки и моноциты также были обнаружены в почках различных видов рыб (Meseguer et al., 1991; Joerink et al., 2006; Rombout et al., 2005; Гордеев и др., 2017). Общее число макрофагов, моноцитов и плазматических клеток в пронефросе скорпены составило около 3 \%. Мы не фиксировали значительных изменений в количестве этих форменных элементов у нерестящихся и зимующих рыб.

Иная ситуация наблюдалась в селезенке. В период функционального покоя на мазках селезенки обнаруживались преимущественно эритроциты. При этом они имели характерную более вытянутую форму, которая присуща стареющим клеткам. Кроме того, на микрофотографиях селезенки часто встречались макроциты (эритроциты крупных размеров). Подобное набухание эритроцитов обычно предшествует их лизису (Потапенко и др., 2006). Вышеуказанные особенности морфологии эритоцитов, а также наличие большого числа эритроцитарных теней позволяют заключить, что селезенка морского ерша выполняет, в первую очередь, функцию утилизации стареющих красных клеток крови, что совпадает с функциональной ролью селезенки у других костистых рыб (AbdelAziz et al., 2010; Witeska, 2013). Кроме того, очевидно, что в данном органе происходит резервирование лимфоцитов и тромбоцитов.

В период функционального покоя в селезенке практически не обнаруживалось бластных форм. У нерестящихся особей, напротив, на мазках отмечались эритробласты. У рыб, как известно, синтез новых эритроцитов осуществляется преимущественно в период нереста (Soldatov, 2005a; Witezka, 2013). В период функционального покоя активность эритропоэтической ткани, как правило, подавлена. Учитывая это, а также тот факт, что на мазках селезенки обнаруживались только бласты эритроцитов, логично предположить, что этот орган выполняет исключительно эритропоэтическую функцию и, таким образом, является органом вторичного эритропоэза.

Отдельный интерес представляет идентификация мелких клеток, обнаруженных в пронефросе и селезенке. Наименьшими размерами характеризовались тромбоциты и малые лимфоциты. Однако разделение малых лимфоцитов и тромбоцитов на мазках в значительной мере носит субъективный характер. Отдельно следует учитывать, что в кроветворной ткани рыб присутствуют также стволовые гемопоэтические клетки, которые по морфологическому профилю идентичны малым лимфоцитам (Spangrude et al., 1988), однако несут совершенно иную функциональную нагрузку. Очевидно, что для однозначного разделения лимфоцитов, тромбоцитов и стволовых клеток недостаточно методов световой микроскопии.

\section{Заключение}

Организация гемопоэза у скорпены в целом соответствует общим принципам кровет- 
ворения у других костистых. Было показано, что пронефрос является основным кроветворным органом, включающим бластные клетки всех ростков гемопоэза. Селезенка служит местом депонирования и утилизации стареющих эритроцитов и функционирует как эри- тропоэтический орган только в период нереста, будучи «резервным» очагом эритропоэза у скорпены. Гемопоэтическая активность обоих органов усиливается в период нереста, это затрагивает, главным образом, процессы эритропоэза.

\section{Список литературы / References}

Гордеев И.И., Балабанова Л.В., Суворова Т.А. (2017) Состав лейкоцитов органов кроветворения антарктического клыкача. Труды ВНИРО, 167: 6-11 [Gordeev I.I., Balabanova L.V., Suvorova T. A. (2017) Composition of leukocytes in the hematopoietic organs of Antarctic toothfish. Proceedings of Russian Federal Research Institute of Fisheries and Oceanography [Trudy VNIRO], 167: 6-11 (in Russian)]

Иванова Н. Т. (1983) Атлас клеток крови рыб: сравнительная морфология и классификация форменных элементов крови рыб. Легкая и пищевая промышленность, 184 с. [Ivanova N. T. (1983) Atlas of fish blood cells: comparative morphology and classification of fish blood cells. Legkaya i pishchevaya promyshlennost', 184 p. (in Russian)]

Маслова М.Н., Тавровская Т.В. (1991) Динамика сезонных изменений в системе красной крови низших позвоночных: сезонная динамика эритропоэза у форели Salmo gairdneri. Журнал эволюиионной биохимии и физиологии, 27(6): 796-798 [Maslova M.N., Tavrovskaya T.V. (1991) Dynamics of seasonal changes in the red blood system of the lower vertebrates: seasonal dynamics of erythropoiesis in the trout Salmo gairdneri. Journal of Evolutionary Biochemistry and Physiology [Zhurnal evolyutsionnoi biokhimii i fiziologii], 27(6): 796-798 (in Russian)]

Потапенко А.Я., Кягова А. А., Тихомиров А. М. (2006) Осмотическая устойчивость эритроичтов. ГОУ ВПО РГМУ, 16 с. [Potapenko А. Ya., Kyagova A. A., Tikhomirov A. М. (2006) The osmotic stability of red blood cells. Russian State Medical University, 16 p. (in Russian)]

Сакун О.Ф., Буцкая Н. А. (1963) Определение стадий зрелости при изучении половых циклов рыб. М., Изд-во АН СССР, 35 с. [Sakun O. F., Butskaya N. А. (1963) Determining the stages of gonadal maturity in the study of reproductive cycles of fish. Moscow, AS USSR, $35 \mathrm{p}$. (in Russian)]

Abdel-Aziz E.S.H., Abdu S. B.S., Ali T.E.S., Fouad H.F. (2010) Haemopoiesis in the head kidney of tilapia, Oreochromis niloticus (Teleostei: Cichlidae): a morphological (optical and ultrastructural) study. Fish Physiology and Biochemistry, 36(3): 323-336

Abràmoff M.D., Magalhães P. J., Ram S. J. (2004) Image processing with ImageJ. Biophotonics International, 11(7): 36-41

Bridges D. W., Cech J. J. Jr, Pedro D. N. (1976) Seasonal hematological changes in winter flounder, Pseudopleuronectes americanus. Transactions of the American Fisheries Society, 105(5): 596-600

Catton W. T. (1951) Blood cell formation in certain teleost fishes. Blood, 6(1): 39-60

Claver J. A., Quaglia A. I.E. (2009) Comparative morphology, development, and function of blood cells in nonmammalian vertebrates. Journal of Exotic Pet Medicine, 18(2): 87-97

Collazos M.E., Ortega E., Barriga C., Rodrìguez A. B. (1998) Seasonal variation in haematological parameters in male and female Tinca tinca. Molecular and Cellular Biochemistry, 183(1-2): 165-168

$$
-205-
$$


De Pedro N., Guijarro A. I., López-Patiño M.A., Martínez-Álvarez R., Delgado M. J. (2005) Daily and seasonal variations in haematological and blood biochemical parameters in the tench, Tinca tinca Linnaeus, 1758. Aquaculture Research, 36(12): 1185-1196

Fänge R., Nilsson S. (1985) The fish spleen: structure and function. Experientia, 41(2): 152-158

Fijan N. (2002a) Morphogenesis of blood cell lineages in channel catfish. Journal of Fish Biology, 60(4): 999-1014

Fijan N. (2002b) Composition of main haematopoietic compartments in normal and bled channel catfish. Journal of Fish Biology, 60(5): 1142-1154

Gordeev I.I., Mikryakov D. V., Balabanova L.V., Mikryakov V.R. (2019) The cell composition of the peripheral blood and some hematopoietic organs in the Antarctic starry skate Amblyraja georgiana (Norman, 1938) (Rajiformes: Rajidae) from the Scotia Sea. Russian Journal of Marine Biology, 45(6): 481-485

Joerink M., Ribeiro C.M.S., Stet R. J.M., Hermsen T., Savelkoul H.F.J., Wiegertjes G. F. (2006) Head kidney-derived macrophages of common carp (Cyprinus carpio L.) show plasticity and functional polarization upon differential stimulation. Journal of Immunology, 177(1): 61-69

Kavadias S., Castritsi-Catharios J., Dessypris A., Miliou H. (2004) Seasonal variation in steroid hormones and blood parameters in cage-farmed European sea bass (Dicentrarchus labrax L.). Journal of Applied Ichthyology, 20(1): 58-63

Kohanestani Z.M., Hajimoradloo A., Ghorbani R., Yulghi S., Hoseini A., Molaee M. (2013) Seasonal variations in hematological parameters of Alburnoides eichwaldii in Zaringol StreamGolestan Province, Iran. World Journal of Fish and Marine Sciences, 5(2): 121-126

Kondera E. (2011) Haematopoiesis in the head kidney of common carp (Cyprinus carpio L.): a morphological study. Fish Physiology and Biochemistry, 37(3): 355-362

Kondera E. (2014) Cell composition of the head kidney of European chub (Squalius cephalus L.). Archives of Polish Fisheries, 22(4): 271-280

Meseguer J., Esteban M. A., Agulleiro B. (1991) Stromal cells, macrophages and lymphoid cells in the head-kidney of sea bass (Dicentrarchus labrax L.). An ultrastructural study. Archives of Histology and Cytology, 54(3): 299-309

Rodriguez F. A.(1995) Basic hematology of Oncorhynchus mykiss (Salmonidae), in Cundinamarca, Colombia. Revista de Biología Tropical, 4: 283-288

Rombout J.H.W.M., Huttenhuis H.B.T., Picchietti S., Scapigliati G. (2005) Phylogeny and ontogeny of fish leucocytes. Fish \& Shellfish Immunology, 19(5): 441-455

Sala-Rabanal M., Sánchez J., Ibarz A., Fernández-Borràs J., Blasco J., Gallardo M. A. (2003) Effects of low temperatures and fasting on hematology and plasma composition of gilthead sea bream (Sparus aurata). Fish Physiology and Biochemistry, 29(2): 105-115

Schneider C. A., Rasband W. S., Eliceiri K. W. (2012) NIH Image to ImageJ: 25 years of image analysis. Nature Methods, 9(7): 671-675

Soldatov A. A. (2005a) Peculiarities of organization and functioning of the fish red blood system. Journal of Evolutionary Biochemistry and Physiology, 41(3): 272-281

Soldatov A. A. (2005b) Physiological aspects of effects of urethane anesthesia on the organism of marine fishes. Hydrobiological Journal, 41(1): 113-126

Soldatov A. A., Pashkova Y.V., Kukhareva T.A. (2012) Micronuclei inclusions in erythrocytes of round goby at various intensity of erythropoietic processes. Hydrobiological Journal, 48(6): 81-85 
Spangrude G. J., Heimfeld S., Weissman I. L. (1988) Purification and characterization of mouse hematopoietic stem cells. Science, 241(4861): 58-62

Tiihonen K., Nikinmaa M. (1991) Substrate utilization by carp (Cyprinus carpio) erythrocytes. Journal of Experimental Biology, 161(1): 509-514

Tort L., Balasch J. C., Mackenzie S. (2003) Fish immune system. A crossroads between innate and adaptive responses. Inmunología, 22(3): 277-286

Witeska M. (2013) Erythrocytes in teleost fishes: a review. Zoology and Ecology, 23(4): 275-281

Zuasti A., Ferrer C. (1989) Haemopoiesis in the head kidney of Sparus auratus. Archives of Histology and Cytology, 52(3): 249-255 